\title{
RAILWAY TRANSPORT AS A DETERMINANT OF IMPROVING THE AVAILABILITY OF AREA TOURISM PRODUCTS (AND ATTRACTIONS)
}

\author{
GRAŻYNA ROSA \\ University of Szczecin \\ Faculty of Management and Economics of Services \\ Department of Marketing of Services \\ e-mail: grazyna.rosa@wzieu.pl
}

\section{\begin{tabular}{l|l} 
JEL CODES & L92, R49, Z32, Z33
\end{tabular} \\ KEYWORDS rail transport, tourism product, region}

ABSTRACT The aim of this article is to present the importance of railway transport as a determinant of improving the availability of tourism products (and attractions), mainly for citizens of selected seaside counties, namely Koszalin and Sławno, as well as tourists within the access to Koszalin and Sławno.

Koszalin and Sławno counties, where holiday rail transport services to the Baltic Sea were opened, were chosen as a research area. In order to achieve the aim, a desk research method, including the available literature and the results of secondary research published by Urząd Transportu Kolejowego (the Office of Rail Transport), the Central Statistical Office (GUS), Przegląd Kolejowy (Railway Review) and Przewozy Regionalne (Regional Transport), which open new opportunities to access the seaside tourism product and shape the communication behaviours of its recipients, was adopted. The article is of overview-research nature.

\section{Introduction}

Contemporary transport market (covering both passenger and freight transport services) is a customer market. The oversupply of services in the passenger transport market is caused by the development of individual motorisation, which meets most of the demand for transport services on the market. 
According to the data provided by GUS, during the period 2000-2017, the number of cars per 1000 inhabitants increased in Poland from 261 to 586 (GUS, 2018, p. 23). This is the largest increase in the motorisation rate among 28 countries of the European Union (Urząd Transportu Kolejowego, 2017a, p. 7). This means that in Poland, a potential rail transport customer can choose between a passenger car and a train.

The selection criteria of passenger transport services mainly include instruments such as product (time and convenience of travel, physical availability and number of connections) and price. The rolling stock is gradually renewed, both by motor and rail undertakings (with the participation of the state and local governments), and customer service, together with the quality of services provided by rail undertakings which are also improving. Drivers can choose from an increasing number of expressways and highways, which in turn, translates into the improvement of safety of travel by car and shorten significantly the travel time between major cities in Poland. On the other hand, local roads still need repairing, they are narrow, often crowded, and require a significant level of concentration from drivers. The communication behaviour of travellers is also changing.

The aim of this article is to present the importance of railway transport as a determinant of improving the availability of tourism products (and attractions), mainly for citizens of selected seaside counties, namely Koszalin and Sławno, as well as tourists within the access to Koszalin and Sławno. Koszalin and Sławno counties, where holiday rail transport services to the Baltic Sea were opened, were chosen as a research area. In order to achieve the aim, a desk research method, including the available literature and the results of secondary research published by Urząd Transportu Kolejowego (the Office of Rail Transport), the Central Statistical Office (GUS), Przegląd Kolejowy (Railway Review) and Przewozy Regionalne (Regional Transport), which open new opportunities to access the seaside tourism product and shape the communication behaviours of its recipients, was adopted.

\section{Passenger rail transport}

The main factors affecting demand in passenger transport are population, distribution and degree of concentration of settlements, level of economic development of the region, purchasing power of the society, time spent on various forms of activities, costs of using individual means of transport in comparison to the prices of public transport services, and the rank of individual demands that make up the quality of the service offer. At the same time, factors that increase the demand for passenger transport (especially in individual transport) can be observed as a result of world social, cultural and professional integration (McLuhan's "world - a common village"); increased living standard of society and the related propensity to travel; developed tourism; and eliminated restrictions in the movement of the population.

A way to increase the use of passenger rail services in Poland may be the application of experience and solutions introduced in other countries. Switzerland has the highest rail usage rate in Europe, with 70 trips per year per capita. Rail travel in this country is characterized by (Urząd Transportu Kolejowego, 2017a, p. 11): 
- high rail availability (large number of trains per day running cyclically e.g. every hour),

- reliability,

- travelling comfort (comfortable and soundproofed carriages available even in regional transport).

Another factor that encourages travellers to use services of railway undertakings is relatively high costs of using a car in and outside the city. In comparison with other European countries, the average number of journeys by rail, per statistical inhabitant in Poland, is not high. The average European citizen travels by train 19 times a year, whereas the Pole only 8 . This shows the untapped potential of the railways, despite the changes that have taken place in recent years. They are primarily reflected in the gradual increase in the number of travellers (Urząd Transportu Kolejowego, 2017a, p. 12).

The following regularities can be observed in the regional transport:

- competitive advantage is often achieved by car transport due to greater availability and the possibility to organize transport "from door to door". This segment of transport experienced a significant increase of competitiveness of rail, as a result of the purchase of modern rolling stock offering high travel comfort by the local governments,

- as far as transport to tourist destinations is concerned, rail transport successfully competes with individual and bus transport. These transports are often characterized by problems regarding the use of cars, e.g. congestion and the lack of parking spaces in tourist destinations. Against this background, the competitiveness of the railways is experiencing a relative growth.

Based on the analysis of the survey results presented by UTK, it can be stated that passengers expect convenient and functional trains, adequate nodal infrastructure (station buildings, train stations, stops), its density, proper service level, timetable adapted to their needs and, above all, minimization of the effort involved with transport organization, which can be ensured by a regular timetable and easy purchase of a train ticket. Railway is a system where each of its element is important and can affect the final choice of means of transport by passengers (Urząd Transportu Kolejowego, 2017b, p. 42).

\section{Availability of tourism product}

The tourism product being the subject of supply on tourist services market is an element of considerations of many Polish authors (Altkorn, 1994; Gołembski, 2009; Meyer, 2006; Niezgoda, 2006; Marciszewska, 2010; Panasiuk, 2010; Mazurkiewicz, 2005; Jędrzejczyk, 2001; Kaczmarek, Stasiak, Włodarczyk, 2010; Zdon-Korzeniowska, 2009; Zmyślony, 2003). The term "tourism product" is widely used, also in relation to the region. Tourism product of the area (Dziedzic, 1988, p. 9) is most often perceived as tangible and intangible elements that constitute the basis of the tourist's ideas and expectations associated with staying at a given place. 
Tourism product of the area of tourist reception (also described as an area's tourist product or tourist area product) arises on many levels and consists of various elements that ultimately should form a coherent whole that is attractive to tourists (Meyer, 2015, p. 239).

According to the concept by V.T.C. Middleton (Zdon-Korzeniowska, 2009, p. 13), a regional tourism product comprises the following factors related to destination: attractions and environment, infrastructure and services, availability, image, and price. In this respect, railways improve the availability of the tourism product of the area as well as the attractions of the destination.

The dictionary definition of the noun 'attraction' means something that is particularly interesting and provides someone with pleasure or entertainment (Uniwersalny słownik języka polskiego $P W N$, 2006). One of the types of attraction is a "tourist attraction", understood as attraction associated with tourism and tourists. Usually it is used in the context of buildings, trails, parks, etc. (Rada Języka Polskiego, 2018).

The concept of "tourist attraction" is most often considered as an element of a tourism product (Prylińska, 2008), which includes touristic resources occurring in the natural state or adapted for use by tourists, which may be the subject of their interest (Medlik, 1995; Kruczek, Sacha, 1997; Nowacki, 2000; Lijewski, Mikułowski, Wyrzykowski, 2008).

The tourist attractiveness of a region, including voivodeships, can be measured by using the value of tourist attractiveness index, which was designated for each voivodeship in Poland in 2016 with the use of the arithmetic average of the tourist attractiveness index for poviats belonging to a given voivodeship and cities with poviat rights (GUS, 2017, p. 20). The research shows that the most attractive voivodeships in terms of tourism are: Małopolskie, Pomorskie and Dolnośląskie, followed by Śląskie and Zachodniopomorskie; that is voivodeships located in the south and north, especially in the coastal belt of the Baltic Sea, Poland. This belt includes Koszalin and Sławno counties which are analysed from the point of view of improving communication availability for residents.

Availability is an environmental feature (physical space, digital reality, information and communication systems, products, services), which allows both healthy people and those with functional limitations (physical and cognitive) to use environment on an equal basis. For many people, availability is a condition for leading independent lives and participating in the social and economic life of the country, local community, school or workplace. (Ministerstwo Inwestycji i Rozwoju, 2018). Availability can be ensured mainly through the implementation of investments of new universal design that aims at facilitating the life of all non-disabled and disabled members of society. Availability can be also understood as removing remaining obstacles by reasonable accommodation, including compensating and assisting technologies. Majority of technological or architectural solutions, which are in use by everyone today, were originally created for people with special needs, for example low-floor buses, spacious toilets, ramps, lack of doorsteps, adjustable furniture, anti-slip surfaces, voice information. Availability also means the possibility of overcoming the distance and financial barrier that determine the use of the offered goods (Ministerstwo Inwestycji i Rozwoju, 2018). 
Tourism product availability comprises economic (price of tickets, as well as travel, catering services, etc.), physical (including mainly transport and time-opening hours, availability hours) and social availability (all facilities and adaptation mainly for the benefit of people with special needs). Availability of tourism product is strongly conditioned by transport availability, which includes both the availability of private individual and public transport - rail and bus. As far as the availability of tourism product for individual customer segments is concerned, it is possible to distinguish availability for tourists and residents (local population). The availability of rail connections discussed hereinafter in Koszalin and Sławno counties concerns mainly inhabitants of seaside towns, but also partially tourists visiting the towns situated in the coastal belt.

\section{Availability of pail links in Koszalin and Slawno counties}

At the initiative of the Department of Infrastructure and Transport of the Marshal's Office of the Zachodniopomorskie region and the Mayor of Koszalin, Mielno Commune and five self-governments of Sławno County, a holiday railway line on the route Koszalin-Mielno, and for the first time (after a six-year break) on the route Sławno-Darłowo was launched in the period from 24 June to 3 September 2017. The distance between Koszalin and Mielno is 14 kilometres. This short distance becomes of significant importance during summer season (after which it is not used), when railbuses of Przewozy Regionalne become an alternative to parallel, congested national road No. 11. The ride from Koszalin to Mielno in extreme conditions, on sunny days during the summer season, can take up to two hours, whereas travel by air-conditioned railbus takes only 15 minutes. In the summer season, there is simply no competition for this type of transport, which results in the growing popularity of this connection (Rynek kolejowy, 2016).

On the other hand, the distance between Sławno and Darłowo is $19 \mathrm{~km}$, with the journey taking 23 minutes. The 418 railway line had undergone a thorough renovation in 2002, after which the track speed for light rail vehicles increased to $100 \mathrm{~km} / \mathrm{h}$. Passenger connections were opened during summer seasons from 2005 to 2011.

The launch of the task was proceeded by concluding agreements with local government authorities on granting financial aid to the Voivodeship in the form of subsidies for financing the full deficit of the transport operator (Rynek kolejowy, 2016).

Voivodeship - organizer of transport as a result of the above-mentioned agreements have received the following funds (Na kolei, 2018; Rynek kolejowy, 2017):

- for the connection Koszalin-Mielno: PLN 235000 (from the City of Koszalin - PLN 210 000; from the Municipality of Mielno - PLN 25 000),

- for the connection Sławno-Darłowo: PLN 187213.47 (from Sławno County - PLN 37 444.69; from City Darłowo - PLN 95 960.73; from Sławno City, Darłowo Commune and Sławno Commune to - PLN 18 721.35).

Table 1 and 2 present the project of the holiday timetable for the analysed routes, in force in 2017 and 2018. 
Tahle 1. Holiday timetable of Koszalin-Mielno in 2017 and 2018

\begin{tabular}{|c|c|c|c|c|c|c|}
\hline No. & Starting station & Departure time & Final station & Arrival time & Running date & $\begin{array}{l}\text { Number } \\
\text { of days }\end{array}$ \\
\hline 1. & Koszalin & $09: 25$ & Mielno & 09:40 & $\begin{array}{l}\text { runs from } 24.06-3.09 \text { on Fridays, } \\
\text { Saturdays, Sundays and } 15.08\end{array}$ & 33 \\
\hline 2. & Mielno & 09:50 & Koszalin & $10: 05$ & $\begin{array}{l}\text { runs from } 24.06-23.09 \text { on Fridays, } \\
\text { Saturdays, Sundays and } 15.08\end{array}$ & 33 \\
\hline 3. & Koszalin & $10: 35$ & Mielno & $10: 50$ & runs $24.06-3.09$ & 72 \\
\hline 4. & Mielno & 11:00 & Koszalin & $11: 15$ & runs $24.06-3.09$ & 72 \\
\hline 5. & Koszalin & $11: 25$ & Mielno & $11: 40$ & runs $24.06-3.09$ & 72 \\
\hline 6. & Mielno & 11:50 & Koszalin & $12: 05$ & runs $24.06-3.09$ & 72 \\
\hline 7. & Koszalin & $12: 25$ & Mielno & $12: 40$ & $\begin{array}{l}\text { runs from } 24.06-3.09 \text { on Saturdays, } \\
\text { Sundays and } 15.08\end{array}$ & 23 \\
\hline 8. & Mielno & 13:01 & Koszalin & $13: 16$ & $\begin{array}{c}\text { runs from } 24.06-3.09 \text { on Saturdays, Sundays and } \\
15.08\end{array}$ & 23 \\
\hline 9. & Koszalin & $13: 30$ & Mielno & $13: 45$ & runs $24.06-3.09$ & 72 \\
\hline 10. & Mielno & $14: 00$ & Koszalin & $14: 15$ & runs $24.06-3.09$ & 72 \\
\hline 11. & Koszalin & $14: 23$ & Mielno & $14: 38$ & $\begin{array}{l}\text { runs from } 24.06-3.09 \text { on Fridays, } \\
\text { Saturdays, Sundays and } 15.08\end{array}$ & 33 \\
\hline 12. & Mielno & $14: 50$ & Koszalin & $15: 05$ & $\begin{array}{l}\text { runs from } 24.06-3.09 \text { on Fridays, } \\
\text { Saturdays, Sundays and } 15.08\end{array}$ & 33 \\
\hline 13. & Koszalin & $15: 35$ & Mielno & $15: 50$ & runs $24.06-3.09$ & 72 \\
\hline 14. & Mielno & $15: 55$ & Koszalin & $16: 10$ & runs $24.06-3.09$ & 72 \\
\hline 15. & Koszalin & $17: 33$ & Mielno & $17: 48$ & runs $24.06-3.09$ & 72 \\
\hline 16. & Mielno & $17: 55$ & Koszalin & $18: 10$ & runs $24.06-3.09$ & 72 \\
\hline 17. & Koszalin & $18: 20$ & Mielno & $18: 35$ & $\begin{array}{l}\text { runs from } 24.06-3.09 \text { on Fridays, } \\
\text { Saturdays, Sundays and } 15.08 \\
\end{array}$ & 33 \\
\hline 18. & Mielno & $18: 42$ & Koszalin & $18: 57$ & $\begin{array}{l}\text { runs from } 24.06-3.09 \text { on Fridays, } \\
\text { Saturdays, Sundays and } 15.08\end{array}$ & 33 \\
\hline 19. & Koszalin & 19:25 & Mielno & $19: 40$ & runs 24.06-3.09 & 72 \\
\hline 20. & Mielno & 20:07 & Koszalin & $20: 22$ & runs 24.06-3.09 & 72 \\
\hline 21. & Koszalin & 21:00 & Mielno & $21: 15$ & $\begin{array}{l}\text { runs from } 24.06-3.09 \text { on Fridays, } \\
\text { Saturdays, Sundays and } 15.08\end{array}$ & 33 \\
\hline 22. & Mielno & $21: 50$ & Koszalin & $22: 05$ & $\begin{array}{l}\text { runs from } 24.06-3.09 \text { on Fridays, } \\
\text { Saturdays, Sundays and } 15.08\end{array}$ & 33 \\
\hline
\end{tabular}

Source: Nowacki (2012).

On the line Koszalin-Mielno, 12 trains started running daily, plus additional 10 trains on Fridays, Saturdays and Sundays, carrying out performance work at 15773 train-km. On the Sławno-Darłowo line, 8 trains started running daily, plus additional 4 trains on Saturdays and Sundays, carrying out performance work at 12624 train-km. (Rynek kolejowy, 2018).

Table 2. Holiday timetable for Sławno-Darłowo trains in 2017 and 2018

\begin{tabular}{|l|c|c|c|c|c|c|}
\hline No. & Starting station & Departure time & Final station & Arrival time & Running date & Interconnection \\
\hline 1 & Sławno & $07: 50$ & Darłowo & $08: 13$ & $23.06-2.09$ (C) & $\begin{array}{c}\text { TLK from Lublin and TLK from } \\
\text { Szczecin }\end{array}$ \\
\hline 2 & Darłowo & $08: 20$ & Sławno & $08: 43$ & $23.06-2.09$ (C) & TLK/IC to Przemyśl \\
\hline 3 & Sławno & $08: 50$ & Darłowo & $09: 13$ & $23.06-2.09$ & $\begin{array}{c}\text { TLK from Gdynia, Regio from } \\
\text { Słupsk, TLK from Przemyśl }\end{array}$ \\
\hline 4 & Darłowo & $09: 23$ & Sławno & $09: 46$ & $23.06-2.09$ & TLK to Kołobrzeg \\
\hline
\end{tabular}




\begin{tabular}{|l|c|c|c|c|c|c|}
\hline No. & Starting station & Departure time & Final station & Arrival time & Running date & Interconnection \\
\hline 5 & Sławno & $10: 00$ & Darłowo & $10: 23$ & $23.06-2.09$ & TLK from Przemyśl Gł. \\
\hline 6 & Darłowo & $13: 05$ & Sławno & $13: 28$ & $23.06-2.09$ & TLK to Białystok \\
\hline 7 & Sławno & $15: 30$ & Darłowo & $15: 53$ & $23.06-2.09$ & $\begin{array}{c}\text { TLK from Katowice, Regio } \\
\text { from Słupsk, Regio from } \\
\text { Koszalin, TLK from Białystok }\end{array}$ \\
\hline 8 & Darłowo & $16: 07$ & Sławno & $16: 30$ & $23.06-2.09$ & $\begin{array}{c}\text { TLK to Olsztyn, TLK to } \\
\text { Kołobrzeg }\end{array}$ \\
\hline 9 & Sławno & $16: 55$ & Darłowo & $17: 18$ & $23.06-2.09$ & $\begin{array}{c}\text { TLK from Szczecin Main } \\
\text { Station, TLK from Łódź Fabr. }\end{array}$ \\
\hline 10 & Darłowo & $17: 30$ & Sławno & $17: 53$ & $23.06-2.09$ & $\begin{array}{c}\text { TLK to Szczecin Main Station, } \\
\text { Regio to Słupsk }\end{array}$ \\
\hline 11 & Sławno & $20: 21$ & Darłowo & $20: 43$ & $23.06-2.09$ on (C) & $\begin{array}{c}\text { IC from Przemyśl, TLK from } \\
\text { from Szczecin Main Station, Regio } \\
\text { fLK from Olsztyn }\end{array}$ \\
\hline 12 & Darłowo & $20: 50$ & Sławno & $21: 12$ & $23.06-2.09$ on (C) & $\begin{array}{c}\text { TLK to Przemyśl (through } \\
\text { Gdynia), TLK to Cracow Main } \\
\text { Station (through Piła) }\end{array}$ \\
\hline
\end{tabular}

$\mathrm{C}$ - runs on Saturdays, Sundays and holidays.

Source: Królewskie Miasto Darłowo.

A single ticket for either line costs PLN 5. The transport operator was obliged to report weekly a number of transported passengers. The analysis of the obtained information indicates that very changing weather would influence the number of passengers transported during holiday. The number of transported passengers on the Sławno-Darłowo and Koszalin-Mielno routes in the summer of 2017 is presented in table 3.

Table 3. Number of transported passengers on the Sławno-Darłowo and Koszalin-Mielno routes in the summer of 2017

\begin{tabular}{|l|c|c|c|c|c|c|c|c|c|c|c|c|}
\hline \multirow{2}{*}{ Route/time } & $24.06-$ & $26.06-$ & $3.07-$ & $10.07-$ & $17.07-$ & $24.07-$ & $31.07-$ & $7.08-$ & $14.08-$ & $21.08-$ & $28.08-$ & $24.06-$ \\
& 25.06 & 2.07 & 9.07 & 16.07 & 23.07 & 30.07 & 6.08 & 13.08 & 20.08 & 27.08 & 3.09 & 3.09 .17 \\
\hline Sławno-Darłowo & 395 & 1196 & 1445 & 1470 & 1506 & 1272 & 1529 & 1379 & 1279 & 1128 & 1086 & 13685 \\
\hline Koszalin-Mielno & 458 & 1935 & 2955 & 3926 & 5472 & 4541 & 4954 & 4623 & 5506 & 3175 & 2033 & 39578 \\
\hline
\end{tabular}

Source: own work based on statistical data.

In 2017, 38588 passengers were transported on the Koszalin-Mielno route, whereas 13685 people chose transport services on the Sławno-Darłowo line. The number of transported passengers in particular time intervals can be presented in the form of a normal distribution function, the maximum of which falls from mid-July until mid-August.

It is difficult to deduce whether these are large numbers from the one-year data. However, taking into account the passenger load factor of trains on the Koszalin-Mielno route at the level of $70 \%$, it can be assumed that it indicates both satisfactory load factor as well as the possibilities of developing this connection. 


\section{Conclusions}

Ensuring economic, physical and social availability guarantees reaching a wider audience opening towards new users, customers and guests, as well as translates into increasing recognition and activity on the tourist market. One of such elements is transport availability, which consists of a network of roads and railways as well as offered transport services. The connections established on the Koszalin-Mielno and Darłowo-Sławno routes, launched and analyzed in the article, constitute an example of improving the availability of attractions (tourism product) mainly for the inhabitants of seaside towns.

The results of the conducted research indicate that the most important factors that shape the availability of the tourist product, as well as consumer behaviour on the passenger rail market include (a) a product (offer) that is appropriately adapted to the needs of the region and which should efficiently use increasingly modern rolling stock and better infrastructure, offer a well-thoughtout timetable structure (suitably adjusted departure times, cyclicality of timetable and frequency of running trains), as well as provide an appropriate level of service; (b) infrastructure and location of stops allowing for their use by the largest possible flows of travellers, as well as their adaptation to the needs of disabled people; and (c) the use of solutions applied in countries where railway realistically competes with passenger cars.

\section{Referencees}

Altkorn, J. (1994). Marketing w turystyce. Warsaw: PWN.

Dziedzic, E. (1988). Obszar recepcji turystycznej jako przedmiot zarządzania turystycznego. Warsaw: Szkoła Główna Handlowa.

Gołembski, G. (ed.) (2009). Kompendium wiedzy o turystyce. Warsaw: Wydawnictwo Naukowe PWN.

GUS (2017). Analiza walorów turystycznych powiatów i ich bezpośredniego otoczenia. Warsaw.

GUS (2018). Transport - wyniki działalności w 2017 roku. Retrieved from: https://stat.gov.pl/obszary-tematyczne/transport-i-lacznosc/transport/transport-wyniki-dzialalnosci-w-2017-roku,9,17.html.

Jędrzejczyk, I. (2001). Nowoczesny biznes turystyczny. Warsaw: Wydawnictwo Naukowe PWN.

Kaczmarek, J., Stasiak, A., Włodarczyk, B. (2010). Produkt turystyczny. Pomyst-organizacja-zarządzanie. Warsaw: Polskie Wydawnictwo Ekonomiczne.

Kruczek, Z., Sacha, S. (1997). Geografia atrakcji turystycznych Polski. Cracow: Oficyna Wydawnicza „Ostoja”.

Królewskie Miasto Darłowo. Rozkład jazdy PKP: Sławno-Darłowo. Retrieved from: https://www.darlowo.pl/ $\mathrm{pl} /$ ?page=imprezy\&impreza $=2129$.

Lijewski, T., Mikułowski, B., Wyrzykowski, J. (2008). Geografia turystyki Polski. Warsaw: Polskie Wydawnictwo Ekonomiczne.

Marciszewska, B. (2010). Produkt turystyczny a ekonomia doświadczeń. Warsaw: C. H. Beck

Mazurkiewicz, L. (2005). Produkt turystyczny w ujęciu marketingu terytorialnego. In: K. Pieńkos (ed.), Konkurencyjność produktu turystycznego (p. 83). Warsaw: Wyższa Szkoła Ekonomiczna.

Medlik, S. (1995). Leksykon podróży turystyki hotelarstwa. Warsaw: PWN.

Meyer, B. (ed.) (2006). Obstuga ruchu turystycznego. Warsaw: Wydawnictwo Naukowe PWN.

Meyer, B. (2015). Konsument na rynku usług turystycznych. In: G. Rosa (ed.) Konsument na rynku ustug (pp. $237-256$. Warsaw: C.H. Beck. 
Ministerstwo Inwestycji i Rozwoju (2018). Program rządowy Dostęność Plus 2018-2025. Retrieved from: https https:// www.miir.gov.pl/media/60878/Program_Dostepnosc_Plus.pdf.

Na kolei (2018). Pociagiem na trasie Koszalin-Mielno Koszalińskie. Będzie to wakacyjne połaczenie. Retrieved from: https:/www.nakolei.pl/pociagiem-trasie-koszalin-mielno-koszalinskie-bedzie-wakacyjne-polaczenie/.

Niezgoda, A. (2006). Obszar recepcji turystycznej w warunkach rozwoju zrównoważonego. Poznań: Wydawnictwo Akademii Ekonomicznej w Poznaniu.

Nowacki, M. (2012). Atrakcje turystyczne: koncepcje, stan, determinanty zadowolenia osób zwiedzających Poznań: Wydawnictwo Akademii Wychowania Fizycznego im. Eugeniusza Piaseckiego,. PKP Polskie Linie Kolejowe SA. Twój portal do podróży! Retrieved from: https://portalpasazera.pl/KatalogiPolaczen?przewoznik=przewo zy-regionalne\&trasa=Koszalin-Mielno\%20Koszali\%C5\%84skie.

Panasiuk, A. (2010). Informacja turystyczna. Warsaw: C.H. Beck.

Prylińska, M. (2008). Podstawowe pojęcia stosowane w geografii turyzmu. Turystyka. Krakowska Akademia. Retrieved from: http://www.turystka07.fora.pl/geografia-turyzmu,32/podstawowe-pojecia-z-geogr-turyzmu-wyklad-ii,154. html (20.10.2018).

Rada Języka Polskiego (2018). Retrieved from: http://www.rjp.pan.pl/index.php?option=com_content\&view=article\&id= 1758:atrakcja-turystyczna\&catid=44\&Itemid=145).

Rynek kolejowy (2016). Pociagiem z Koszalina do Mielna w 15 minut. Retrieved from: https://www.rynek-kolejowy.pl/ wiadomosci/pociagiem-z-koszalina-do-mielna-w-15-minut-77062.html.

Rynek kolejowy (2017). Wrócą pociągi Sławno-Darłowo. Retrieved from: https://www.rynek-kolejowy.pl/wiadomosci/ wroca-pociagi-slawno--darlowo-80488.html.

Rynek kolejowy (2018). Stawno-Darlowo: znamy ceny i tabor. Będzie połaczenie całoroczne? Retrieved from: https:// www.rynek-kolejowy.pl/wiadomosci/slawno--darlowo-znamy-ceny-i-tabor-87296.html.

Uniwersalny stownik języka polskiego PWN (2006). Warsaw: Wydawnictwo Naukowe PWN.

Urząd Transportu Kolejowego (2017a). Wykorzystanie i potencjat kolejowych przewozów pasażerskich w Polsce. Warsaw. Urząd Transportu Kolejowego (2017b). Koleje pasażerskie w województwach-dynamika zmian. Warsaw.

Zdon-Korzeniowska, M. (2009). Jak kształtować regionalne produkty turystyczne? Teoria i praktyka. Cracow: Wydawnictwa Uniwersytetu Jagiellońskiego.

Zmyślony, P., Niezgoda, A. (2003). Popyt turystyczny. Uwarunkowania i perspektywy rozwoju. Poznań: Wydawnictwo Akademii Ekonomicznej.

Zmyślony, P. (2008). Partnerstwo i przywództwo $w$ regionie turystycznym. Poznań: Wydawnictwo Akademii Ekonomicznej. 


\section{TRANSPORT KOLEJOWY JAKO DETERMINANTA POPRAWY DOSTĘPNOŚCI PRODUKTÓW (I ATRAKCJI) TURYSTYCZNYCH OBSZARU}

SŁOWA KLUCZOWE

STRESZCZENIE transport kolejowy, produkt turystyczny, region

Celem artykułu jest przedstawienie znaczenia transportu kolejowego jako determinanty poprawy dostępności produktów (i atrakcji) turystycznych, głównie dla mieszkańców wybranych powiatów nadmorskich - koszalińskiego i sławieńskiego oraz turystów w zakresie dostępu do Koszalina i Sławna.

Jako obszar badawczy przyjęto powiaty koszaliński i sławieński, w których uruchomiono wakacyjne przewozy kolejowe nad Morze Bałtyckie. Do realizacji celu przyjęto metodę desk research uwzględniającą dostępną literaturę oraz wyniki badań wtórnych publikowanych przez Urząd Transportu Kolejowego, GUS, Przegląd Kolejowy oraz spółkę Przewozy Regionalne, które otwierają nowe możliwości dla dostępności nadmorskiego produktu turystycznego i kształtowania zachowań komunikacyjnych jego odbiorców. Artykuł ma charakter przeglądowo-badawczy. 